ENVIRONMENTAL RESTORATION PROGRAM

\section{Review of Passive Groundwater Remediation Systems: Lessons Learned Oak Ridge Y-12 Plant, Oak Ridge, Tennessee}

This document has been approved by the $Y$-12 Plant Technical Information Office for release to the public. Date: $8 / Z \& / q 7$

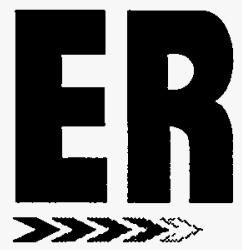


Entech, Inc.

contributed to the preparation of this document and should not be considered an eligible contractor for its review. 


\section{DISCLAIMIER}

\section{Portions of this document may be illegible in electronic image products. Images are produced from the best available original document.}




\title{
Review of Passive Groundwater Remediation Systems: \\ Lessons Learned \\ Oak Ridge Y-12 Plant, Oak Ridge, Tennessee
}

Date Issued-August 1997

\author{
Prepared by \\ Entech, Inc. \\ Oak Ridge, Tennessee \\ under subcontract ICK-AEN02V \\ Prepared for the \\ U.S. Department of Energy \\ Office of Environmental Management \\ under budget and reporting code EW 20 \\ Environmental Management Activities at the \\ OAK RIDGE Y-12 PLANT \\ Oak Ridge, Tennessee 37831 \\ managed by \\ LOCKHEED MARTIN ENERGY SYSTEMS, INC. \\ for the \\ U.S. DEPARTMENT OF ENERGY \\ under contract DE-AC05-84OR21400
}




\section{PREFACE}

This report was prepared in accordance with requirements under the Comprehensive Environmental Response, Compensation, and Liability Act. This document provides the Environmental Management Program with a review of existing passive groundwater systems. This work was performed under WBS number 1.1.02.41.10.34.20, ADS 2302, "Bear Creek Valley."

\section{DISCLAIMER}

This report was prepared as an account of work sponsored by an agency of the United States Government. Neither the United States Government nor any agency thereof, nor any of their employees, makes any warranty, express or implied, or assumes any legal liability or responsibility for the accuracy, completeness, or usefulness of any information, apparatus, product, or process disclosed, or represents that its use would not infringe privately owned rights. Reference herein to any specific commercial product, process, or service by trade name, trademark. manufacturer, or otherwise does not necessarily constitute or imply its endorsement, recommendation, or favoring by the United States Government or any agency thereof. The views and opinions of authors expressed herein do not necessarily state or reflect those of the United States Government or any agency thereof. 



\section{CONTENTS}

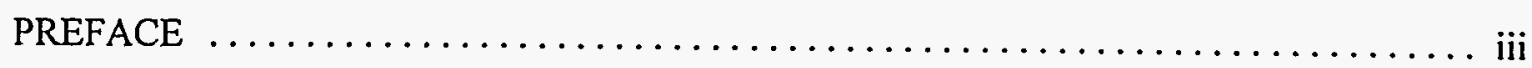

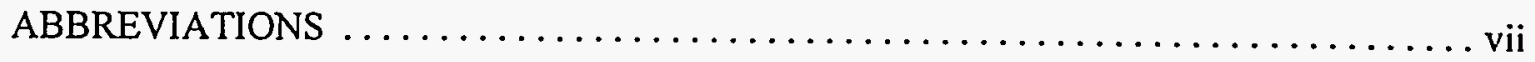

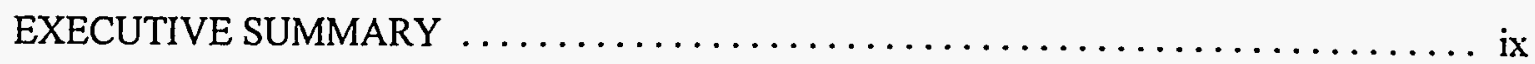

1. INTRODUCTION $\ldots \ldots \ldots \ldots \ldots \ldots \ldots \ldots \ldots \ldots \ldots \ldots \ldots \ldots \ldots \ldots \ldots \ldots \ldots$

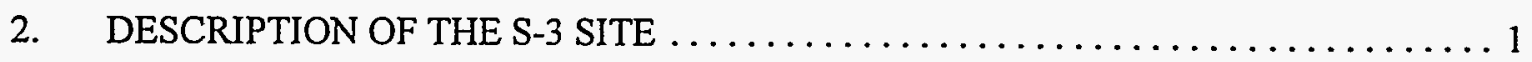

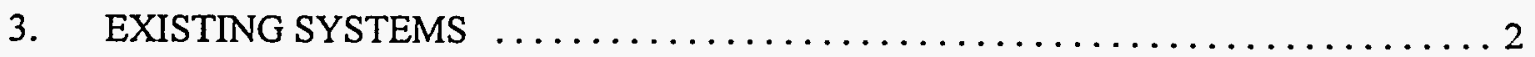

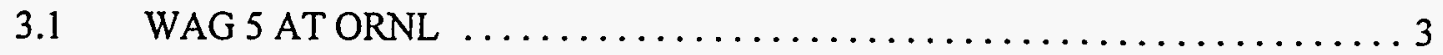

3.2 PORTSMOUTH GASEOUS DIFFUSION PLANT, PIKETON, OHIO $\ldots \ldots \ldots 4$

3.3 WATERLOO, CANADIAN FORCES BASE, BORDEN, ONTARIO $\ldots \ldots \ldots 6$

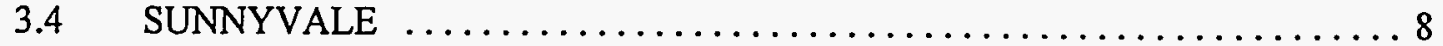

3.5 MOUNTAIN CITY ................................ 8

3.6 ELIZABETH CITY, NC (U.S. COAST GUARD SUPPORT CENTER) ......9

3.7 DURANGO, CO (URANIUM MINE TAILINGS) $\ldots \ldots \ldots \ldots \ldots \ldots \ldots$

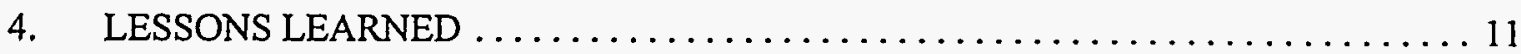

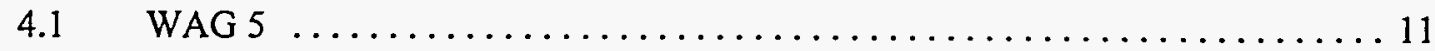

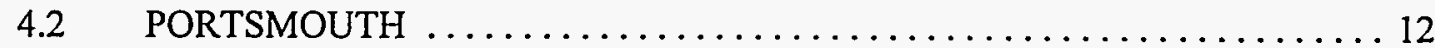

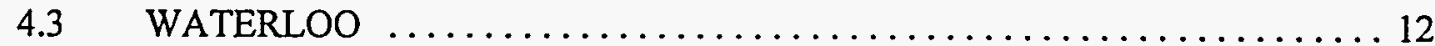

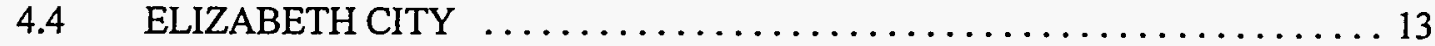

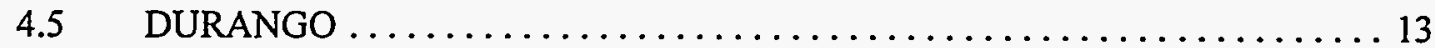

5. SUMMARY AND RECOMMENDATIONS $\ldots \ldots \ldots \ldots \ldots \ldots \ldots \ldots \ldots \ldots \ldots \ldots \ldots \ldots$ 



\section{ABBREVIATIONS}

DO dissolved oxygen

DOE Department of Energy

ORNL Oak Ridge National Laboratory

VOC volatile organic compound

WAG waste area grouping 


\section{EXECUTIVE SUMMARY}

One of the proposed solutions for treatment of the contaminated groundwater in the Bear Creek Valley is the installation of a passive treatment system. Such a system would use a reactive media installed in a continuous trench or in a gate as part of a barrier wall and gate system. This report evaluates information on five similar systems [no information was available on two additional systems] and evaluates the shortcomings and the advantages of each. Section 5 provides a short summary of the findings and presents some recommendations on how to avoid some of the common problems encountered with the existing systems. 



\section{INTRODUCTION}

The S-3 site is located in Bear Creek Valley, where a plume of groundwater contaminated with uranium, technetium, nitrate, and several metals is migrating toward Bear Creek.

Contaminated groundwater has long been treated by the pump-and-treat approach in which the groundwater is pumped to the surface, treated, and then discharged on the surface or injected back into the ground. This technique has proven to be costly and less effective than originally anticipated. A more recently developed approach is passive remediation. This is a method that uses the natural flow of groundwater by having it pass through a treatment medium, which is located in the aquifer or in a treatment building.

Several design options are available. A common design is a trench filled with the reactive medium placed across the groundwater path. The treatment medium in the trench has a higher hydraulic conductivity than the native aquifer. In this design, the trench is long enough and deep enough to intercept the contaminant plume and wide enough that the residence time of water in the treatment medium is sufficient to reduce the contaminant concentration to acceptable levels. A major disadvantage of this approach is that if the system fails because of depletion of the treatment medium, clogging by inorganic precipitates, biological fouling or other causes, a large effort is required to renew the system. The advantage of passive remediation is that it is truly passive and requires no maintenance or input of outside energy after construction to effect groundwater cleanup.

A variation on passive remediation is the funnel-and-gate system. Impermeable walls (these comprise the funnel) are constructed to direct the groundwater to a central point (the gate) where the groundwater passes through the treatment medium before continuing through the aquifer. The treatment medium may be permanently installed, or the system may be configured so that containers of the treatment medium can be removed and replaced as necessary. This system is more costly to build, but the treatment medium may be renewed at only a fraction of the cost of the original construction, and the useful life of the system is nearly unlimited.

A third approach uses a trench, funnel, or horizontal well to capture the groundwater. It is then directed by gravity flow through a piping system to a treatment building. This requires sufficient topographic relief for gravity flow to and discharge from the treatment area. The treatment medium is placed in canisters that can be easily replaced and monitored for performance.

The purpose of this technical memorandum is to describe the characteristics of seven existing passive groundwater remediation systems and to identify similarities to the S-3 site and problems encountered in these systems that may give insight into possible problems and solutions at the S-3 site.

\section{DESCRIPTION OF THE S-3 SITE}

The S-3 site is located in Bear Creek Valley, where a plume of groundwater contaminated with uranium, technetium, nitrate, and several metals is migrating toward Bear Creek. The area has been 
extensively modified by human activity, but consists of unconsolidated soil overlying bedrock that is fractured at the soil-bedrock interface. The groundwater flows principally near the soil-bedrock interface, but the direction of flow is often influenced by preferential flow paths originating from soil disturbance during plant construction and operations.

The design of the passive remediation system is a trench, approximately $200 \mathrm{ft}$ long, $2 \mathrm{ft}$ wide. and $22 \mathrm{ft}$ deep to the top of competent bedrock. The trench, which slopes approximately $2 \mathrm{ft}$ from the northeast toward the southwest, will be constructed perpendicular to the local groundwater flow direction and will be backfilled with a high-conductivity, inert backfill except for a 20 -ft-long section near the downstream end of the trench. This section will be filled with zero-valent iron as the treatment medium. After passing through the treatment medium, the groundwater will reenter the inert backfill and flow back into the aquifer. The design also provides for pumping the treated water to the surface.

\section{EXISTING SYSTEMS}

There are seven existing systems to be reviewed as part of this effort. The characteristics of each system to be described are flow rates, discharge, clogging, residence time, media deployment methods, treatment by-products, and hydraulic performance. This review will identify characteristics of each site that are similar to those at the S-3 site, as well as problems that have occurred and could potentially occur at the S-3 site and their proposed solutions.

The seven sites are listed in Table 1 below.

Table 1. Existing System Characteristics

\begin{tabular}{|c|c|}
\hline Site & Passive Remediation System \\
\hline WAG 5 at ORNL & Seep capture and removal of ${ }^{90} \mathrm{Sr}$ with sodium chabazite \\
\hline Portsmouth & $\begin{array}{l}\text { Plume capture with horizontal well and treatment of trichloroethylene (TCE) using } \\
\text { iron filings }\end{array}$ \\
\hline Waterloo & Trench using iron filings for in situ removal of VOCs from groundwater \\
\hline Sunnyvale & Trench using iron filings for in situ removal of VOCs from groundwater \\
\hline Mountain City & Trench using iron filings for in situ removal of VOCs from groundwater \\
\hline Elizabeth City & Trench using iron filings for in situ removal of VOCs from groundwater \\
\hline Durango & $\begin{array}{l}\text { Capture of runoff from uranium mine tailings and treatment by low carbon steel } \\
\text { wool in containers }\end{array}$ \\
\hline
\end{tabular}

Information has been collected on all the sites except Sunnyvale and Mountain City, for which no information is available. The remaining five sites are described in this section; Sect. 4 addresses the applicability of each to the S-3 site. 


\title{
3.1 WAG 5 AT ORNL
}

\section{Project Contact(s)}

\author{
Bill Barton \\ P-SQUARED Technologies, Inc. \\ P. O. Box 22668 \\ Knoxville, TN 37933 \\ (423) $691-3668$
}

\section{Problem Statement}

Radioactive waste was buried in unlined trenches at Waste Area Grouping (WAG) 5 at Oak Ridge National Laboratory (ORNL) from 1958 until the 1970s. Direct rainfall and shallow stormflow leaches radioactive contaminants (particularly ${ }^{90} \mathrm{Sr}$ ) from these wastes into the groundwater, which flows toward Melton Branch. Some of it is discharged into Seep C, just upgradient of the stream. This seep contributed approximately $15 \%$ of all radioactive contamination entering the White Oak Creek embayment from ORNL. In 1995, the average ${ }^{90} \mathrm{Sr}$ concentration in water captured at Seep C was $386 \mathrm{Nci} / \mathrm{L}$.

\section{Treatment Medium}

The treatment medium is sodium chabazite (a naturally occurring zeolite), that has been previously used as an ion exchange resin at the ORNL radioactive water treatment plant. Field tests using Seep C water indicated that a residence time of $20 \mathrm{sec}$ would be sufficient to effectively remove ${ }^{90} \mathrm{Sr}$ from the water.

\section{Barrier Construction, Deployment Method}

The design of the interception trench and treatment facility was based on the results of a groundwater model constructed for the site. The groundwater that previously discharged through Seep C is intercepted by a 75-ft-long french drain excavated to bedrock. The bottom of the french drain is sloped from both ends toward the low point where the intercepted water flows by gravity through a pipe to the treatment vault. The water then enters a manifold from where it may be directed to any combination of four 55-gal primary treatment canisters and then to corresponding secondary canisters before being routed to a common point and discharged to Melton Branch. Sampling ports are located at the inflow manifold, the discharge from each primary and secondary treatment canister, and the discharge from the treatment vault.

Dye tracing during laboratory tests on horizontal flow through a rectangular box containing zeolite indicated some bypassing of the zeolite by preferred flow along the edges of the box. Vertical cylindrical canisters designed for use with activated charcoal were found to yield better contact of the groundwater with the treatment media.

\section{Flow Rate}

Flow rates anticipated during design ranged from 1.1 to 4.5 gal per minute (gpm). 


\section{Residence Time}

Based on these flow rates, the residence time for the water to be in contact with the treatment medium range from $3 \mathrm{~min}$ to $10 \mathrm{~min}$, much longer than the $20 \mathrm{sec}$ that the field tests indicated was necessary to remove the ${ }^{90} \mathrm{Sr}$.

\section{Chemical Effectiveness}

Greater than $99.9 \%$ of ${ }^{90} \mathrm{Sr}$ has been removed on a consistent basis.

\section{By-products}

Unknown

\section{Hydraulic Performance} canisters.

The hydraulic performance has been good when there has been free flow through the treatment

\section{Clogging and Other Problems}

The only major problem has been clogging of the treatment canisters by iron oxide. This is thought to be caused by absorption of oxygen in the french drain and subsequent reaction of oxygen with iron in the groundwater and also with the treatment medium. This has led to frequent cleaning and replacement of the treatment canisters. The design anticipated replacing the canisters at approximately 1-year intervals, but replacement has occurred more frequently. Attempts to avoid clogging have included introducing nitrogen into the french drain to shield the water from oxygen and to minimize solution of oxygen into the water, and adding a dispersing agent to the groundwater upstream of the treatment canisters to prevent flocculation of the iron. These corrective measures have been only moderately successful. Clogging of the canisters continues to be a problem. When the canisters are clogged, water backs up in the french drain, and it is suspected that contaminated water bypasses the treatment system.

\section{Papers and Documents}

Barton, W. D., Craig, P. M., and Stone, W. C. "Two Passive Groundwater Treatment Installations at DOE Facilities."

Borders, D. M, Hicks, D. S., and Scanlon, T. M. Effectiveness of ${ }^{90}$ Sr Removal Actions in the White Oak Creek Watershed, 1995. ORNL Technical Bulletin FY96BUL2.V2, July 1996.

\subsection{PORTSMOUTH GASEOUS DIFFUSION PLANT, PIKETON, OHIO}

\section{Contact(s)}

Bill Barton

P-SQUARED Technologies, Inc.

P. O. Box 22668

Knoxville, TN 37933

(423) 691-3668 


\section{Problem Statement}

A TCE plume known as the $X-120$ plume originated from TCE spills beginning about 40 years ago. The plume is located in the southwest corner of the plant and is migrating very slowly toward the southwest. The area has been extensively reworked during various construction projects. The plume is bordered on the northwest by low permeability fill and on the southeast by a higher permeability aquifer. The Gallia aquifer is composed of gravel, sand, and silt, with localized zones of high hydraulic conductivity. The highest hydraulic conductivity zones in the Gallia are in the lower layers. The Gallia is underlain by the low permeability Sunbury shale at a depth of approximately $10 \mathrm{~m}$. Above the Gallia is a low hydraulic conductivity zone, the Minford clay, so that most of the groundwater flow and the plume migration occurs in the lower layers of the Gallia.

\section{Treatment Medium}

Three treatment media are being tested in this system. They are (1) fine grade iron filings (equivalent to $40 \mathrm{mesh}$ ), (2) stock iron filings ( 8 to $50 \mathrm{mesh}$ ), and (3) palladized iron filings composed of 40 mesh iron filings chemically plated with palladium (at $0.05 \%$ of iron). Media 1 and 2 are placed in three 55-gal drums each and medium 3 in a 6-in. layer in one drum.

\section{Barrier Construction, Deployment Method}

Groundwater modeling using the model FRAC3D indicated that the plume could be effectively captured by means of a horizontal well in the high conductivity zone of the Gallia. The well is 2 in. in diameter and $1344 \mathrm{ft}$ long, with a screen length of $500 \mathrm{ft}$. The head difference between the well screen and the treatment facility is approximately $10 \mathrm{ft}$. The water collected in the well flows by gravity to a treatment building constructed in a natural depression. Before contacting the treatment media, the water passes through a prefilter to remove suspended materials and to scavenge dissolved oxygen (DO) from the groundwater, and then through a sand layer. The water flows by gravity through the treatment media and then through another sand layer.

\section{Flow Rate}

The flow rate predicted by the model was $1.8 \mathrm{gpm}$, with a TCE concentration between 140 and $200 \mathrm{ppb}$. The measured flow rate has ranged from 0.8 to $1.2 \mathrm{gpm}$, with a TCE concentration of 100-200 ppb.

\section{Residence Time}

Assume flow is divided into three equal flows each of $0.35 \mathrm{gpm}$. Residence time is computed as:

$$
T=\frac{\text { Pore Volume }}{Q}
$$

The pore volume for media 1 and 2 is 77.6 gal and for medium 3, approximately 7.1 gal. With variable flow rates of approximately $0.35 \mathrm{gpm}$ through each medium, the corresponding residence times are $222 \mathrm{~min}$ for media 1 and 2 and $20 \mathrm{~min}$ for medium 3. 


\section{Chemical Effectiveness}

Initially, all media reduced concentration from $170 \mathrm{ppb}$ to $<2 \mathrm{ppb}$. After 51 days of operation, effluent concentrations were $<2 \mathrm{ppb}$ for medium $1,3 \mathrm{ppb}$ for medium 2 , and $12 \mathrm{ppb}$ for medium 3 . This indicates possible degradation of the treatment media.

\section{By-products}

The target contaminant at this facility is TCE. The By-products include cis-1, 2-DCE, vinyl chloride, ethene, and ethane.

\section{Hydraulic Performance}

The hydraulic performance matches the groundwater model well. There is no evidence of short circuiting, as the 55-gal drums are effective in preventing short circuiting in the treatment media.

\section{Clogging and Other Problems}

The system is working well, with only some minor clogging problems. However, TCE half lives have increased and then decreased for each of the treatment media but are still longer than the initially measured half lives. High DO initially caused iron oxide precipitation and fouling. Replacing tygon tubing with copper tubing prevented oxygen diffusion into the system and solved the problem. Iron oxide should not be a problem in trench applications due to the low DO in groundwater. Gas (probably hydrogen from dissociation of water by zero valent iron) was causing high pressure and slowing of water flow. Manual vents were installed in the system to fix this problem. The rate of gas generation has slowed as the system has continued to operate, probably due to formation of a passivation layer on the iron filings. Buildup of biomass (probably sulfate reducing bacteria) has caused problems with the prefilter but not yet with the treatment drums. This may be a problem in the future.

\section{Papers and Documents}

Barton, W. D., Craig, P. M., and Stone, W. C. "Two Passive Groundwater Treatment Installations at DOE Facilities."

Liang, L., West, O. R., Korte, N. E., Goodlaxson, J. D., Anderson, F. D. , Welch, C. A., and Pelfry, M. May 1996. "Interim Report on X-749/X-120 Groundwater Treatment Facility, a Field-Scale Test of Trichloroethylene Dechlorination using Iron Filings."

\subsection{WATERLOO, CANADIAN FORCES BASE, BORDEN, ONTARIO}

\section{Contact(s)}

M. J. Baker, University of Waterloo, Ontario

David Smyth, University of Waterloo, Ontario, (519) 888-4567

DSMYTH@SCIBORG.UWATERLOO.CA

David Blowes, University of Waterloo, Ontario, (519) 888-4878 


\section{Problem Statement}

This is a demonstration project at a site where a previous study was done. Native aquifer material was brought to residual saturation ( $5 \%$ by volume) with respect to a mixture of chlorinated solvents [chloroform (TCM), TCE, and tetrachloroethene (PCE)] as well as gypsum to serve as a source of sulphate to be used as a conservative tracer. The source with dimensions of $1.5 \times 1.0 \times 0.5$ $\mathrm{m}$ was placed $1 \mathrm{~m}$ below the water table and $2-3 \mathrm{~m}$ below the ground surface. The site consists of an unconfined sand aquifer underlain at a depth of approximately $9 \mathrm{~m}$ by a thick, clayey silt deposit. The groundwater velocity is approximately $8.2 \mathrm{~cm} /$ day, and the plume increases from $1 \mathrm{~m}$ thick near the source to $2 \mathrm{~m}$ at a distance of $20 \mathrm{~m}$ downgradient. In the transverse direction, the width averaged approximately $1 \mathrm{~m}$. The downgradient extent of the plume was controlled by a pump-and-treat system.

The purposes of the study were to:

- determine if the reaction rate was influenced by the presence of geologic porous materials;

- determine if the in situ performance could be predicted on the basis of laboratory tests; and

- evaluate the long-term performance of the reactive material under natural hydrogeochemical conditions.

\section{Treatment Medium}

The treatment medium used was granular iron. A series of batch and column tests were done in the laboratory.

\section{Barrier Construction, Deployment Method}

The barrier was installed $5.5 \mathrm{~m}$ downgradient from the source by excavating and backfilling with $22 \%$ by weight iron and $78 \%$ concrete sand. The dimensions are $5,5 \mathrm{~m}$ long, $1.6 \mathrm{~m}$ wide and $2.23 \mathrm{~m}$ high, with the upper surface $3.77 \mathrm{~m}$ below ground surface. It was then covered by an $8 \mathrm{~cm}$ layer of concrete sand and then clean native soil to the surface. The measured hydraulic conductivities of the barrier and of the native aquifer were $4.37 \times 10^{-2} \mathrm{~cm} / \mathrm{sec}$ and $7.24 \times 10^{-3}$ $\mathrm{cm} / \mathrm{sec}$, respectively.

\section{Flow Rate}

Flow rates and directions varied seasonally. Flow velocity was $8.2 \mathrm{~cm} /$ day.

\section{Residence Time}

The residence time based on a flow velocity of $8.2 \mathrm{~cm} /$ day and a barrier thickness of $1.6 \mathrm{~m}$ is 19.5 days. This is greater than the required 15 days determined from the column tests in the laboratory, but the barrier thickness was $1.6 \mathrm{~m}$ instead of $1.24 \mathrm{~m}$ due to construction practicalities.

\section{Chemical Effectiveness}

The most complete data set was collected on day 299 of the test. The maximum contaminant concentrations upgradient and downgradient of the barrier were measured as $253,000 \mu \mathrm{g} / \mathrm{L}$ and $12,000 \mu \mathrm{g} / \mathrm{L}$ for TCE and 43,000 and $3,760 \mu \mathrm{g} / \mathrm{L}$ for PCE. The flux of these contaminants at these 
same locations, computed from a contouring program, indicated that $90 \%$ of the TCE and $86 \%$ of the PCE were dechlorinated in the barrier. There appeared to be no deterioration of performance during the 474 days of data available.

Half lives computed from field data were 117 hours for TCE and 147 hours for PCE. These are more than six times as long as the half lives computed from laboratory column experiments. These results indicate that the dechlorination reaction is only pseudo first order, and the half life may increase with time.

\section{By-products}

CDCE, 1,1-DCE and tDCE were detected downgradient of the barrier at concentrations of 254, 86 , and $54 \mu \mathrm{g} / \mathrm{L}$, respectively. Vinyl chloride was not detected. Ethene, butene, and propene were also detected, but not quantified. Chloride was detected at a concentration of $65 \mathrm{mg} / \mathrm{L}$ downgradient of the barrier.

\section{Hydraulic Performance}

The hydraulic performance was not noticed to be deficient. Contours of TCE and PCE concentrations upgradient, downgradient, and inside the barrier indicated only insignificant fluxes of contaminants bypassed the barrier.

\section{Clogging and Other Problems}

No major clogging problems were reported, although some inorganic precipitates and perhaps biofouling may be expected as the system continues to operate.

\section{Papers and Documents}

O'Hannesin, S. F. "A Field Demonstration of a Permeable Reaction Wall for the In Situ Abiotic Degradation of Halogenated Aliphatic Organic Compounds," M.S. Thesis, University of Waterloo, 1993.

Gillham, R. W., O'Hannesin, S. F. Enhanced Degradation of Halogenated Aliphatics by Zero-Valent Iron, Ground Water Vol 32 No 6, November-December 1994.

\subsection{SUNNYVALE}

No information available.

\subsection{MOUNTAIN CITY}

No information available. 


\subsection{ELIZABETH CITY, NC (U.S. COAST GUARD SUPPORT CENTER)}

\section{Contact(s)}

Bill Schmithorst

Parsons Engineering Science, Inc.

401 Harrison Oaks Blvd, Suite 210

Cary, NC 27513

(919) 677-0080

Bill_Schmithorst@Parsons.com
Jim Vardy

U.S. Coast Guard Support Center, Bldg. 19

Elizabeth City, NC 27909

(919) 335-6847

javardy@ecsu.campus.mci.net

\section{Problem Statement}

A plume contaminated with hexavalent chromium and TCE is migrating toward a river approximately $300 \mathrm{ft}$ from the source. Maximum concentrations detected are $5 \mathrm{mg} / \mathrm{L}$ chromium $[\mathrm{Cr}$ (VI)] and $10 \mathrm{mg} / \mathrm{L}$ TCE. The area is relatively flat and approximately 7-9 ft above sea level. The aquifer is fine sand, clay, and silt with a low permeability, clayey, fine sand at a depth of $24 \mathrm{ft}$. The depth to groundwater is $6-7 \mathrm{ft}$. The plume is migrating principally in a high conductivity layer $(\sim 1 \mathrm{ft} /$ day) approximately $16-22 \mathrm{ft}$ below the surface.

\section{Treatment Medium}

The treatment medium used was granular zero-valent iron.

\section{Barrier Construction, Deployment Method}

The original idea was to use a funnel and gate system, but the location of buildings would not allow this option. A continuous trencher was used to place iron in the trench as the native material was excavated. The trench is $150 \mathrm{ft}$ long, $24 \mathrm{ft}$ deep, and $2 \mathrm{ft}$ thick. It was constructed across the plume and has a higher hydraulic conductivity than the native soil.

\section{Flow Rate}

No information is available, but an estimate should be available from the groundwater model performed by Waterloo using FRAC3D.

\section{Residence Time}

Residence time is unknown. Feasibility studies indicated that a residence time of 17 hours would be needed and would require a $16 \mathrm{in}$. barrier thickness. Therefore, a residence time of approximately $(24 / 16) \times 17=25.5$ hours will be assumed since the barrier thickness is 24 in.

\section{Chemical Effectiveness}

$\mathrm{Cr}$ (VI) has been reduced to levels below detection and TCE to $<50 \mu \mathrm{gL}$. Vinyl chloride has been reduced from $\sim 50 \mu \mathrm{gL}$ to $<2 \mu \mathrm{gL}$. It may be that these levels are due to residual chlorinated compounds desorbing from the soil and the levels will decrease over the next few sampling rounds. $\mathrm{pH}$ was increased to $>10$ in the barrier. The system has now been in operation for 9-10 months and is intended to continue $10-20$ years. 
By-products

No by-products were reported.

Hydraulic Performance

No problems with hydraulic performance were reported.

\section{Clogging and Other Problems}

No clogging problems are evident yet. There may be some mineral precipitation including manganese $(\mathrm{Mn})$ in the high $\mathrm{pH}$ environment. The only real problem documented was that the concrete apron broke during construction due to weight of the trencher carrying the iron filings for emplacement. This is now being repaired.

\section{Papers and Documents}

Schmithorst and Vardy. "Use of a Reactive Permeable Iron Barrier to Remediate Contaminants in Groundwater U.S. Coast Guard Support Center, Elizabeth City, North Carolina."

\subsection{DURANGO, CO (URANIUM MINE TAILINGS)}

\section{Contact(s)}

Diane Marozas, Hydrogeologist

Sandia National Laboratory

(505) 845-0011 FAX (505) 894-0543

Bryan Dwyer, Engineer

Sandia (505) 845-9894

Bruce Thomson, UNM

(505) 277-4729 FAX (505) 277-1988

bthomson@unm.edu

\section{Problem Statement}

Rainfall on uranium mine tailings drains to a settling pond. The drainage is contaminated with uranium. This project is a demonstration/research project to test various treatment media for removing uranium.

\section{Barrier Construction, Deployment Method, Treatment Medium}

There are four treatment media being tested. The flow from the mine tailings will be passed through each of the four media in turn. One of these is "Cercona" foam, an iron-impregnated foam and a low-carbon steel wool. These media are contained in $3 \times 2 \times 4 \mathrm{ft}$ boxes with internal baffles to force flow through the media. The other two tests consist of a constructed "aquifer" in which the 
leachate flows vertically through the treatment media. These media are steel wool and a mixture of steel wool and copper.

\section{Flow Rate}

Flow rates were not reported but are small enough that only one medium can be tested at a time.

\section{Residence Time}

Residence time was not reported.

\section{Chemical Effectiveness}

For medium 1, nitrate has been decreased from $30 \mathrm{ppm}$ to less than detect, sulfate is largely unaffected, and uranium is reduced from $6 \mathrm{ppb}$ to nondetect. The other tests cells have not yet been operated.

\section{By-products}

No by-products were reported.

\section{Hydraulic Performance}

No problems with hydraulic performance were reported.

\section{Clogging and Other Problems}

The boxes are nearly airtight, and there has been some clogging. The box for medium 1 has not yet been opened so the source of the clogging is unknown. Guesses include hydrogen gas pressure, and biofouling. The lesson learned is to design the front end of the treatment unit to prevent precipitation and other forms of clogging.

\section{Papers and Documents}

Dwyer, B. P. FY 1996 Final Report, Durango, County Umtra Site Field Scale Demonstration of Reactive Barrier Systems, Sandia National Laboratory, February 1997.

\section{LESSONS LEARNED}

This section describes aspects of the systems reviewed that offer some insight into the resolution of problems that may occur at the S-3 site.

\subsection{WAG 5}

The geology is very similar to that at S-3. The overburden is unconsolidated and is underlain by bedrock that is fractured at the upper surface. Much of the groundwater flow occurs near the top of the bedrock, and the flow paths are influenced by disturbances due to human activity. The 
experience at WAG 5 has shown that groundwater in this geologic setting can be successfully captured in a highly permeable trench and conducted to a treatment site. There is sufficient vertical relief in the surface topography and in the groundwater table to allow discharge to the surface.

The major problem encountered has been clogging of the treatment canisters by iron oxide. The groundwater at both WAG 5 and the S-3 site contains significant quantities of iron. The water in the french drain is very shallow and in contact with atmospheric oxygen. Attempts to eliminate iron oxide formation by blanketing the french drain with nitrogen and adding chemicals to the water upstream of the treatment area have been only moderately successful. The design of the S-3 unit will allow much less solution of oxygen into the water and iron oxide precipitation should be less of a problem. If this problem does occur, the design allows little opportunity for modification. The only clearly available action is to introduce dispersing agents into the groundwater through strategically placed wells or to introduce oxidizing agents through such wells and precipitate the iron before it reaches the treatment medium.

\subsection{PORTSMOUTH}

The geology at Portsmouth is not so similar to S-3, but groundwater flow has been extensively impacted by anthropogenic influences. Recharge at the Portsmouth site is restricted by the overlying Minford clay, resulting in a low groundwater flow rate. Capture of the plume has been very successful due to the accuracy of the groundwater model on which the design was based. This argues for spending significant effort on achieving a detailed understanding of the hydrogeology of the site prior to the treatment unit design.

Treatment is being carried out in a building where various treatment media can be tested. Information is still being collected on treatment effectiveness. The only serious problems encountered are the production of hydrogen gas by the dissociation of water, clogging by iron oxide, and possibly biological fouling of the prefilter. The iron oxide problem was largely eliminated by removing pathways for atmospheric oxygen to diffuse into the treatment system. This implies that a system such as the one being designed for the S-3 site should have only minor iron oxide problems. There is little opportunity for atmospheric oxygen to dissolve in the water to be treated, and the groundwater is nearly anoxic.

\subsection{WATERLOO}

This site is much different from the S-3 site, with the only similarities being the contaminant of concern and the design using a permanent subsurface barrier. The geology consists of an unconfined sand aquifer underlain by a thick, clayey silt deposit.

Two lessons can be learned from this pilot-scale experiment. Some inorganic precipitates and biofouling may be expected during several years of operation. The more important result is that first order half lives for degradation of the contaminants determined from laboratory batch and column tests may underestimate the actual half lives in the field. These differences may be due to changes in the reactive medium over time and/or the fact that the reaction is only pseudo first order and that the laboratory results gave only approximations to the decay rate even with fresh zero-valent iron. 


\subsection{ELIZABETH CITY}

The geology is similar to that at Waterloo and different from the S-3 site. A well-constructed groundwater model was used in the design process and undoubtably contributed to the success of the project. The period of operation is too short to know what problems may occur, but there is some evidence of mineral precipitation in an environment with a $\mathrm{pH}>10$.

\subsection{DURANGO}

There is very little similarity between Durango and the S-3 site. Although the pilot study is less than $25 \%$ complete, Bryan Dwyer's opinion was that the most important lesson from this experiment is to design the entrance to the treatment area to prevent inorganic precipitation, biofouling, and any other foreseeable clogging mechanisms.

\section{SUMMARY AND RECOMMENDATIONS}

Five passive groundwater remediation systems have been reviewed. Information on two others has not been received. The systems include a french drain and a horizontal well to collect groundwater and direct it into treatment canisters, subsurface permeable treatment barriers constructed across the path of the plume, and the routing of leachate from mine tailings into treatment containers. The contaminants removed from the water are ${ }^{90} \mathrm{Sr}$, uranium, and volatile organic compounds (VOCs). The treatment media are sodium chabazite for ${ }^{90} \mathrm{Sr}$ and zero-valent iron for uranium and VOCs. Capture of the plume and treatment effectiveness have been generally good to excellent, but a few potential problems have been encountered. Some of these problems, suggestions for avoiding or solving them, and other lessons learned are listed below.

- A thorough understanding of the site hydrogeology is essential to improve the chances of achieving a design that will capture the contaminant plume. Use of a properly configured groundwater model can be useful in evaluating various system options.

- Laboratory batch and column tests yield computed half-lives for degradation of the contaminants. These half-lives are underestimations of those observed under field conditions. This may_be_due_to_degradation of the_treatment medium,_contaminantconcentrations_outside the range of the experiments, or a misunderstanding of the reaction kinetics involved in the treatment. Either a better understanding of these issues is required or a substantial factor of safety must be included in the design.

- Gas, probably hydrogen, has been generated in some of the systems using iron as the treatment medium. Provision for venting this gas must be made if the treatment medium is in a closed container.

- Various types of fouling or clogging of the treatment medium may occur. These range from inorganic precipitation to biofouling by bacteria. The hydrogeochemistry must be well understood to predict these problems. The most bothersome and most probable is clogging by iron oxide. This has occurred in several installations and has proven difficult to control. One option for avoiding or resolving this problem includes a design that prevents contact of atmospheric oxygen with the groundwater, particularly when the groundwater is high in 
dissolved iron. Other approaches are to introduce an oxidizing agent through wells upstream of the treatment barrier to precipitate the iron before it reaches the treatment barrier or to introduce chemicals to disperse the iron oxide or prevent it from forming.

- If it appears that the clogging problems cannot be avoided, it is advisable to design a funneland-gate system with the treatment medium in a canister that can be removed and replaced at minimal expense. While the initial construction would be more expensive, the system should be able to operate almost indefinitely. 


\section{DISTRIBUTION}

1. L. V. Asplund

2. M. A. Cox

3. J. A. Davis

4. V.M. Forsberg

5. C. S. Haase

6. J. C. Henderson

$7 . \quad$ R. L. Marcum

8. H. C. Newsom

9. P. T. Owen

10. L. B. Raulston

11. L. G. Schaffer

12-14. J. H. Vanderlan

15. D. B. Watson

16. S. A. White

17. M. C. Wiest

18. File-EMEF DMC-RC

19. R. Adkisson, Entech, 560 Oak Ridge Turnpike, Suite 2, Oak Ridge, TN 37830

20. P. A. Salpas, Science Applications International Corporation, 800 Oak Ridge Turnpike, P.O. Box 2502, Oak Ridge, TN 37831

21. D. Moss, Science Applications International Corporation, 800 Oak Ridge Turnpike, P.O. Box 2502, Oak Ridge, TN 37831

22. B. Sams, Jacobs Engineering Group, Inc., 125 Broadway Avenue, Oak Ridge, Tennessee 37830 